\title{
AS CONFIGURAÇÕES DO SUJEITO LÍRICO E DO SUJEITO HISTÓRICO NA POESIA BRASILEIRA CONTEMPORÂNEA: A VOZ POÉTICA COMO FERRAMENTA DE REAPROXIMAÇÃO DE VOZES E NARRATIVAS SILENCIADAS
}

\author{
THE SETTINGS OF THE LYRIC SUBJECT AND THE HISTORICAL \\ SUBJECT IN CONTEMPORARY BRAZILIAN POETRY: THE \\ POETIC VOICE AS A TOOL FOR THE RAPPROCHEMENT OF \\ SILENCED VOICES AND NARRATIVES
}

\author{
Carlos Wender Sousa Silva' \\ [http://orcid.org/0000-0001-8955-4023] \\ DOI: 10.30612/raido.v15i38.14862
}

\begin{abstract}
RESUMO: O presente artigo visa discutir a ficcionalizaçăo da voz poética e o endereçamento lírico em monólogos dramáticos como uma possibilidade de expressăo de vozes emergentes, historicamente silenciadas e violentadas. Dois poemas sâo discutidos: Vozes mulheres (2008), de Conceiçấo Evaristo, e Da humanidade levada pelas águas (2015), de Graça Graúna. O eu poético é investigado nessas duas produçôes artísticas como mecanismo de expressăo năo apenas de uma subjetividade, mas igualmente como manifestaçấo de uma coletividade que traz marcas do seu tempo histórico (ADORNO, 2003), que reúne lutas, afetos, dores, encontros e desencontros com os quais ela precisa lidar cotidianamente. Busca-se apontar características da complexa relaçấo entre a voz do eu poético, sua individualidade, e as vozes múltiplas que se interpenetram àquela. Nesse sentido, adota-se uma noçâo mais ampla de monólogo dramático, defendida por Alan Sinfeld (1977), cuja concepçâo afirma ser um monólogo dramático todo poema no qual o falante seja alguém diferente do poeta, ou seja, sujeito lírico e sujeito histórico se distinguem.
\end{abstract}

Palavras-chave: Poesia brasileira contemporânea; vozes emergentes; sujeito lírico; sujeito histórico.

ABSTRACT: This article aims to discuss the fictionalization of the poetic voice and lyrical addressing in dramatic monologues as a possibility of expression of emerging voices, historically silenced and violated. Two poems: Vozes mulheres (2008), by Conceiçăo Evaristo, and Da humanidade levada pelas águas (2015), by Graça Graúna are discussed. The poetic self is investigated in these two artistic productions, as a mechanism of expression not only of subjectivity but also as a manifestation of a collectivity that brings marks of its historical time (ADORNO, 2003), which brings together struggles, affections, pains, encounters and disagreements that it needs to deal with every day. It

1 Universidade de Brasília (UnB) 
seeks to point out characteristics of the complex relationship between the voice of the poetic self, its individuality, and the multiple voices that interpenetrate that last one. In this sense, it adopts a broader notion of dramatic monologue, defended by Alan Sinfeld (1977), whose conception claims to be a dramatic monologue in every poem in which the speaker is someone different from the poet, in other words, lyrical subject and historical subject are distinguished.

KEYWORDS: Contemporary Brazilian poetry; emerging voices; lyrical subject; historical subject.

\section{ALGUMAS CONSIDERAÇÕES SOBRE MONÓLOGO DRAMÁTICO, FICCIONALIZAÇÃO DA VOZ POÉTICA E ENDEREÇAMENTO LÍRICO}

Sabe-se que as teses e vertentes críticas que debatem a funçâo do autor săo muitas e nâo se limitam a um único gênero literário. Num dos capítulos de Monólogo dramático e outras formas de ficcionalizaçâo da voz poética (2020), Vagner Camilo e Fabio Cesar Alves apresentam algumas delas que serviram de base a essa obra e que me ajudam a estabelecer uma concepçăo geral de monólogo dramático, ficcionalizaçâo da voz poética e endereçamento lírico, questōes cujas discussōes recaem aqui sobre os poemas de Conceiçâo Evaristo e de Graça Graúna. Os dois pesquisadores apresentam, por exemplo, a concepçấo de Shira Wolosky que defende que o poema lírico é uma multiplicidade de vozes, mesmo quando o eu lírico se apresenta de uma forma una, "o que descarta a ideia de uma voz poética "pura", "singular" ou "impessoal"' (CAMILO \& ALVES, 2020, p. 13). 0 monólogo dramático evidencia esse aspecto. É importante ressaltar que a dramatizaçấo nâo anula a voz do poeta, ela pode adentrar a personagem ou se opor a ela. "Nesse sentido, o termo "voz" deve ser entendido em sentido amplo, como um eixo em torno do qual diferentes pontos de vista se articulam no texto poético" (CAMILO \& ALVES, 2020, p. 14). Os jogos entre a voz do poeta, os movimentos de autorrepresentaçăo e a persona criada se interpenetram. "Esse jogo entre o eu e as máscaras poéticas revela a amplitude e a variabilidade das fronteiras entre o eu-lírico e as vozes representadas no poema" (CAMILO \& ALVES, 2020, p. 14).

Os autores discutem também alguns elementos do endereçamento lírico, tal como a ideia de a heterogeneidade de destinatários no poema lírico construída por Antonio Rodriguez, na qual o eu e o tu săo indeterminados, constituídos por diversos referentes, mas com uma funçâo definida ligada à enunciaçaao: "a da recepçâo fictícia ou empírica, tendo, por sua vez, a possibilidade de se converter em locutor" (CAMILO \& ALVES, 2020, p. 14). Essa $2^{\mathrm{a}}$ pessoa pode-se dar a partir do desdobramento reflexivo do eu num tu, há, pois, uma identificaçâo do eu com o destinatário do enunciado. Existe também a referência à $3^{a}$ pessoa, onde ocorre um distanciamento a partir de construçóes impessoais. Vagner Camilo e Fabio Cesar Alves (2020) trazem ainda um parâmetro das contribuiçōes dos estudos dos norte-americanos Allen Miller, Helen Vendler e Barbara Herrnstein Smith. Para esta última, todo poema é, em última análise, um monólogo dramático, ou seja, "um ato fictício de fala que deve ser reconstruído no ato da leitura" (CAMILO \& ALVES, 2020, p. 17). Falar, expressar săo atos verbais fictícios e importa menos que o personagem ou a persona se diferencie do poeta. Jonathan Culler, por sua vez, defende uma relaçáo bem mais complexa entre o eu e o poeta, cujo enunciado poético nâo se limita a uma imitaçăo ficcional de expressâo pessoal. 
O artigo Uma introduçâo ao monólogo dramático (2020), da pesquisadora Shelley Jane Roche-Jacques, do mesmo livro, aborda inicialmente o artigo The Dramatic Monologue, de Ina Beth Sessions, publicado em 1947, que foi a primeira tentativa importante de definir o gênero. Sessions apontou sete atributos necessários para um monólogo dramático: "falante, audiência, ocasiăo, revelaçăo de caráter, interaçăo entre falante e audiência, açâo dramática e açăo que ocorre no presente" (1947, p. 508, apud ROCHE-JACQUES, 2020, p. 21). As setes categorias de Sessions sâo um ponto de partida para as discussóes contemporâneas sobre o monólogo dramático, embora apresente um caráter taxonômico e limitado, segundo Shelley Roche-Jacques. Outro estudo apresentado pela autora é The Dramatic Monologue (1977), de Alan Sinfield, que explorou as distinçôes entre falante, poeta e leitor do monólogo dramático. "Sinfield (1997, p. 21) adora a perspectiva ampla e abrangente de que o monólogo dramático é qualquer poema no qual se indica que o falante năo é o poeta" (ROCHE-JACQUES, 2020, p. 27). Ele também se volta para a distinçâo entre o significado do falante e o significado do poema. Porém, é a consciência do leitor face às projeçôes e intençôes do poeta que estabelece essa disparidade. Sinfield conclui que o monólogo dramático é em algum grau mais dialógico que monológico porque apresenta a permanente tensâo entre o eu que fala e o eu do poeta.

Na acepçăo contemporânea do termo, monólogo dramático é recorrentemente usado no sentido amplo de Sinfeld e se refere a "qualquer poema no qual o falante parece ser alguém que nâo o poeta" (ROCHE-JACQUES, 2020, p. 32). Shelley Roche-Jacques (2020), entretanto, questiona esse uso indiscriminado e lembra, por exemplo, daqueles casos em que năo há uma identificaçăo explícita do eu como um personagem específico, em que o falante pode se mascarar através do poeta. A pesquisadora enfatiza que a expressăo "monólogo dramático" se constituiu ao longo do tempo em torno de ambiguidades a respeito da sua própria concepçăo e delimitaçôes. A ideia divergente da palavra "dramático" é o elemento principal dessa confusâo. Sessions, por exemplo, fala da "açâo dramática" como o "movimento narrativo interno ao incidente ou enredo "desdobrado" pelo falante" (ROCHE-JACQUES, 2020, pp. 37-38). Relacionado a esse critério de açâo dramática como movimento narrativo está a "açăo no presente", fato que coloca o leitor na posiçăo de testemunha do evento original e que ao menos uma parte da açăo se concretiza no momento presente do poema.

Em The Dramatic Monologue (1996), Elisabeth Howe aborda essa ambiguidade e defende que o falante se envolve num drama. Aqui, dramático assumiria seus dois sentidos: o primeiro de distinçăo entre falante e poeta, o segundo, de drama como a efetivaçâo de uma tensâo ou conflito. Shelley Roche-Jacques (2020) rebate nesse segundo ponto ao afirmar que essa tensăo ou conflito pode ou náo aparecer no monólogo dramático. Para a autora do artigo, Alan Sinfield emprega o sentido mais lógico. Ele defende que tenhamos uma noçâo mais ampla da concepçâo de poemas como monólogos dramáticos. "Por isso, ele declara usar "dramático" de uma maneira básica e clara para "distinguir a fala que se manifesta evidentemente como ficçấo daquela proferida por pessoas na realidade"'" (1977, p. 71, apud ROCHE-JACQUES, 2020, p. 39). Todo esse debate em torno das possibilidades de um monólogo dramático me interessa na medida em que analiso as vozes que emergem através do eu poético e as tensóes entre sujeito lírico e sujeito histórico. 


\title{
VOZES POÉTICAS FEMININAS: DISPUTAS DISCURSIVAS E HISÓRICAS
}

Em Vozes mulheres (2008), de Conceiçăo Evaristo, há a presença de um eu poético em primeira pessoa que remete a outras vozes que ecoaram e ecoam no movimento do tempo histórico e, por isso mesmo, se fazem presentes na própria voz desse eu poético. Nesse poema, a ficcionalizaçăo da voz poética é usada como ferramenta de recuperaçăo de vozes sociais que foram historicamente silenciadas e marginalizadas, como podemos ver a seguir:

\author{
A voz de minha bisavó \\ ecoou criança \\ nos poróes do navio. \\ Ecoou lamentos \\ De uma infância perdida. \\ A voz de minha avó \\ ecoou obediência \\ aos brancos-donos de tudo. \\ A voz de minha măe \\ ecoou baixinho revolta \\ no fundo das cozinhas alheias, \\ debaixo das trouxas, \\ roupagens sujas dos brancos, \\ pelo caminho empoeirado \\ rumo à favela.
}

As vozes de uma bisavó e de uma máe que ecoam no tempo e no espaço remetem à ideia de permanência das estruturas de poder e de silenciamento dessas mesmas vozes no decorrer do processo histórico. Vozes que ecoam lamentos e obediência nos revelam a dimensăo real dessas estruturas de dominaçăo e de controle. Ee é do lamento da bisavó e da revolta da máe, lá dos fundos das cozinhas alheias, que o eu lírico vai se estruturando. A voz poética se vale dessas marcas identitárias e históricas para, entǎo, por meio da força da própria linguagem poética, fazer todas essas vozes até entăo silenciadas emergirem no tempo histórico e se fazerem ouvir. A voz poética coloca em evidência e denuncia o que já năo se pode esconder: o racismo estrutural, o classismo, a misoginia, as histórias roubadas dessas mulheres, a exploraçăo a qual estiverem submetidos seus corpos, a marginalizaçăo de suas vozes que agora ecoam na voz do eu poético. Essas vozes que percorreram poróes de navios, que ecoaram "obediência aos brancos-donos de tudo", que foram silenciadas no fundo das cozinhas alheias.

$\mathrm{Na}$ estrofe seguinte, a voz poética marca os limites e as possibilidades entre a manifestaçăo da sua subjetividade e esse compromisso coletivo que assumiu de representaçăo e de reparaçăo de bocas tapadas pelas măos do dominante, expondo por meio da sua própria voz essas outras tantas vozes submetidas às diferentes condiçóes de controle e de apagamento. 


\section{A minha voz ainda \\ ecoa versos perplexos, \\ com rimas de sangue \\ e fome.}

Essa estrofe revela como o processo de ficcionalizaçáo da voz poética remete a tantos deslocamentos sociais, políticos, econômicos e geográficos coletivos. O que vemos é uma poética que reage diante da açăo do sistema explorador, racista, classista e imperialista. É da perplexidade, do sangue e da fome, resultantes da implementaçăo desse sistema exploratório na nossa sociedade, que ecoa e se firma a voz do sujeito lírico nesse poema. A poética, para além da expressăo lírica e estética presente na própria estrutura do poema, se revela um espaço de emancipaçáo, de luta e de desejo de transformaçáo social. O sujeito lírico assume legitimamente essa posiçăo de representante das vozes historicamente violentadas e marginalizadas. E justamente por manter sua autonomia em relaçăo ao sujeito histórico - à autora do poema -, o sujeito lírico pode se deslocar para diferentes contextos temporais e geográficos, realidades a princípio divergentes, e, ainda assim, se identificar com as vozes marginalizadas nas grandes periferias do Brasil, aquelas que se localizam nos campos, no sertăo, no interior, ou em qualquer outro espaço em que as relaçóes entre as pessoas sejam estabelecidas cotidianamente por meio de mecanismos de violência e de critérios desiguais e injustiça. A voz poética traz para o primeiro plano da linguagem corpos mutilados e bocas amordaçadas daqui ou de qualquer outro local do mundo. Essa característica tem a ver com a própria força e potencialidade de alcance da linguagem poética, mecanismo muito bem desenvolvido pela poetisa Conceiçăo Evaristo.

A ideia de permanência e de resistência estâo bem marcadas na lírica da autora, como pode-se observar também nas duas últimas estrofes:

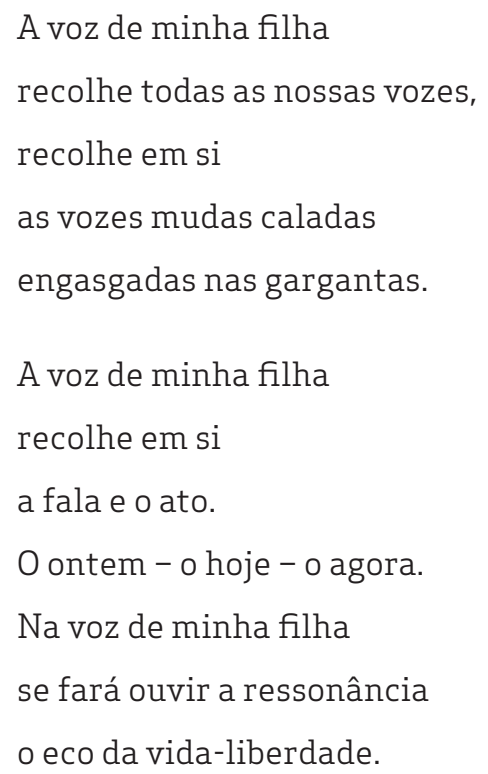

A voz dessa filha é o futuro, o vigor, a força que emerge da luta diária. É essa voz que "recolhe em si / as vozes mudas caladas / engasgadas nas gargantas". Essa voz recolhe "a fala e o ato", ou seja, ela tem força discursiva e poética, assim como mostra-se vital e 
humana na medida em que é corpo e voz capaz de lutar, reivindicar, contestar, se opor, nâo se deixar silenciar, erguer a cabeça, peito firme, e, outra vez, agir em favor da coletividade e contra os interesses e as fronteiras impostas pelas forças dominantes. A voz poética traz a voz de uma filha que é esperança, humanidade e vitalidade. E uma voz que năo surgiu de repente, do último instante, como algo ainda incerto ou inseguro. É uma voz que se constitui de tantas outras vozes do passado, ela se forma da experiência das vozes anteriormente silenciadas, das expressôes apagadas, dos sonhos roubados. Por isso, é uma voz do ontem e do hoje, que se mostra viva agora. E năo mais se intimida diante dos mecanismos de silenciamento, de apagamento e de controle. "Na voz de minha filha / se fará ouvir a ressonância / o eco da vida-liberdade". O que vemos nesses últimos versos é a força da coletividade e o desejo de mudança. E assim transitamos entre o que ora é a subjetividade da voz poética ora é a manifestaçăo de um coletivo, o encontro de diversas narrativas semelhantes e singulares entre si.

Nesse sentido, destaco que a poética se traduz como manifestaçăo năo apenas da subjetividade do eu lírico, mas igualmente das vozes que antes e depois se apresentam diante da continuidade e das reconfiguraçóes dos processos históricos. A poesia lírica é tomada como ferramenta discursiva do ontem e do hoje, e a estrutura mesma do poema e a posiçáo da voz poética dentro do poema caminham nesse sentido. Poesia lírica remete ao que J. Culler discutiu em Retórica, Poética e Poesia, do livro Teoria literária: uma introduçâo (1999). Para o autor, a lírica se constitui tanto da estrutura de palavras organizadas pelo poeta quanto pelos interesses que o permeiam e a forma como o leitor e o discurso se relacionam com ele. O poema é compreendido como uma construçăo verbal: "uma questâo importante é a relaçâo entre o sentido e os traços nâo-semânticos da linguagem, tais como som e ritmo" (CULLER, 1999, p. 76). O poema concebido como um ato discursivo imediatamente se coloca diante de uma "relaçâo entre o ato do autor que escreve o poema e o do falante ou "voz" que fala ali" (CULLER, 1999, p. 76). Assim, há de um lado o indivíduo histórico e do outro a voz poética específica. Como elemento intermediário entre esses dois elementos, Culler afirma estar a imagem da voz poética. $\mathrm{O}$ autor destaca que "ao pensar sobre lírica, é crucial começar com uma distinçâo entre a voz que fala e o poeta que fez o poema, criando dessa maneira essa figura da voz" (CULLER, 1999, p. 77). As situaçôes poéticas, as atitudes e as preocupaçóes, o tom de voz em alguns casos podem se confundir com a voz do poeta, mas nâo é o que sempre ocorre.

De uma maneira geral, os poemas se valem das operaçōes retóricas para colocar em movimento as nossas reflexóes, apreensôes, nossa experiência no tempo e no espaço e pode, assim, tratar de aspectos da condiçăo humana a partir de uma perspectiva muito mais ampla tendo em vista essa abordagem poética e artística da linguagem. Acredito que é de disso que trata o texto Retórica, Poética e Poesia (1999), de J. Culler. Outro estudioso do tema, o crítico francês Dominique Combe, no texto A referência desdobrada: o sujeito lírico entre a ficçâo e a autobiografia (2009), parte do apontamento de que saber se o "eu" poético ou romanesco é fictício ou năo é uma questâo que já nâo cabe, pois tanto num quanto no outro a figura do autor se ausenta e o que se revela é um "eu" sujeito da enunciaçăo. "Desse fato decorre que só pode haver, a rigor, distinçâo entre o sujeito da enunciaçăo e o sujeito do enunciado" (COMBE, 2009, p. 114).

Nesse sentido, a noçăo de sujeito lírico abrange uma leitura diferente das perspectivas biografistas e historicistas, segundo o autor. Para o crítico francês, o sujeito poético - o poeta - é o conteúdo da poesia lírica. "O sujeito lírico é a expressăo do poeta 
na sua autenticidade" (COMBE, 2009, p. 115). Ou seja, a poesia lírica é compreendida como a manifestaçáo do "eu" do poeta. O poeta năo se reverte num personagem, mas nele mesmo. Dominique Combe aponta ainda que para que haja uma concepçăo "biografizante", a "sinceridade" do poeta precisa ser colocada em primeiro plano, baseada na figura na referencialidade de um "sujeito ético", na medida em que se fala de um sujeito năo só psicológico, mas igualmente moral e político. "Assim, o sujeito poético, que é igualmente o sujeito "real", é também e, sobretudo, um sujeito "ético", plenamente responsável por seus atos e palavras, e, por isso mesmo, um sujeito de direito" (COMBE, 2009, pp. 115-116).

Dominique Combe enfatiza também que "a gênese do conceito de "sujeito lírico" é, portanto, inseparável da questâo das relaçôes entre literatura e biografia, e do problema da "referencialidade" da obra literária" (COMBE, 2009, p. 120). E é importante sua leitura a respeito da concepçáo de poema autobiográfico.

O conceito de "eu lírico" parece entâo se contrapor diretamente ao lirismo autobiográfico e, particularmente, contra a possibilidade de uma poesia autobiográfica em sentido estrito, conforme a definiçáo de "pacto autobiográfico" proposta por Philipe Lejeune. O critério autobiográfico, com efeito, repousa na identificaçáo entre autor, narrador e personagem confundidos no emprego da primeira pessoa (COMBE, 2009, p. 120).

Ficçấo e verdade sâo elementos que se interpenetram. "É por certo grau de ficçăo que a "verdade" autobiográfica pode ser atingida" (COMBE, 2009, p. 123). Elas se apoiam mutuamente, conforme argumenta Dominique Combe. Nesse sentido, o autor julga importante relativizar a polaridade criada pela crítica entre sujeito empírico e sujeito lírico, ou ainda, entre autobiografia e ficçăo, ou poesia e verdade. Todo discurso referencial se constitui a partir de uma parte de invençăo e imaginaçăo e reflete, em diferentes graus, elementos autobiográficos, uma vez que a arte é produzida a partir da experiência de mundo e das vivências do próprio artista. Acredito que a ficçăo, ainda que resultado de um processo de criaçăo, năo pode ser considerada como resultado unicamente da imaginaçâo do artista, como uma invençâo do nada. Tal como defende Käte Hamburger, a experiência ficcional dialoga com o sujeito real, no gênero lírico ou em outros. A matéria prima do poeta se encontra nos anseios, desejos, realizaçôes, imaginários e deslocamentos da sua subjetividade e da coletividade concomitantemente. Esses movimentos sociais, culturais, psicológicos e históricos se dâo no âmbito da realidade em que o artista e o seu grupo se encontram. E a poesia, a literatura em geral, é essa possibilidade de transpor esses movimentos para um âmbito estético que nos ofereça perspectivas e olhares muito mais complexos sobre esses mesmos movimentos. Vozes mulheres, de Conceiçâo Evaristo, emprega de forma muito significativa esse movimento.

Essa "confusâo" entre sujeito lírico e sujeito empírico pode ser compreendida como a própria possibilidade da literatura de colocar em cena múltiplas vozes poéticas no plano textual - Vozes mulheres (2008) traz já no título as marcas dessa pluralidade de vozes poéticas - . Ela reflete muitas das potencialidades discursivas e estéticas da arte e năo é de modo algum um aspecto que coloca em oposiçăo ficçăo e verdade. A tensâo constante entre esses dois elementos é fundamental à produçâo literária que visa representar e adentrar as zonas sociais, históricas, políticas, geográficas e psicológicas 
das relaçóes humanas. E essa tensăo é interessante também do ponto de vista da estrutura do texto literário, uma vez que ela revela, acredito, a complexidade e as tensôes da própria natureza humana. É um aspecto que pode nos orientar no sentido de construir leituras e estabelecer relaçóes com a vida a partir do que o texto em si nos oferece. Essa tensâo também é responsável por ampliar as possibilidades de desdobramento e de alcance da narrativa ficcional. Pode ser, por fim, um convite para a elaboraçâo de propostas e de pensamento crítico diante dos fragmentos e dos vestígios da realidade identificados no texto.

Da humanidade levada pelas águas - em memória de Aylan Kurdi - (2015), de Graça Graúna, me parece que também se caracteriza por essa multiplicidade de vozes que juntas constituem a voz poética. O poema é uma homenagem ao menino sírio de três anos, Aylan Kurdi, que morreu afogado em 2015 em Bodrum, na Turquia. A fotografia do corpo da criança numa praia sendo recolhido por um policial circulou o mundo e denunciou um problema da contemporaneidade, a crise migratória.

\author{
Viver é perigoso, \\ o poeta dizia. \\ Assim mesmo insistimos \\ em fazer a travessia. \\ Viver é perigoso, \\ mas seguimos \\ vestidos de coragem \\ na ânsia de encontrar \\ o olhar generoso \\ o abraço apertado \\ a mâo amiga \\ que acolham os nossos sonhos... \\ Em meio à travessia \\ a humanidade \\ é levada pelas águas \\ e tudo que me fica \\ é uma tênue esperança \\ que se alastra pelo mundo \\ nos sonhos do pequeno anjo \\ de asas partidas. \\ Apesar das muralhas \\ e dos arames farpados, \\ o direito à Paz nos aproxima. \\ Viver é perigoso, \\ mas insistimos...
}


Já no início, há um jogo - uma dualidade - entre o sujeito lírico e o sujeito empírico: "Viver é perigoso, o poeta dizia". A voz poética remete ao ofício do poeta e da poetisa, a criaçăo e a linguagem como ferramenta dessa produçăo. Em seguida, essa voz poética nos convida a fazer uma travessia coletiva pela vida. Argumenta que a coragem da qual podemos nos revestir precisa ser compartilhada entre os diferentes membros dessa coletividade. É também um olhar generoso, um abraço apertado, uma mâo amiga, um consolo, uma palavra de conforto que, diante de situaçóes limites, impostas no meio dessa travessia, sâo açôes e gestos aos quais podemos recorrer e nos apoiarmos uns aos outros e seguirmos juntos. O poema é um convite ao luto coletivo. Logo, o poema fala também em trocas afetivas, em compartilhamento de sonhos e de lutas. Essa luta se torna muito mais palatável quando organizada e combatida por meio de diversas máos. Essa busca pelo olhar generoso, abraço apertado e măo amiga que acolham nossos sonhos é açâo fundamental às nossas vidas. E é da experiência das águas que levam embora a humanidade que podemos resgatar nossa esperança e nossos sonhos. E, assim, articular nossas açóes em torno de projetos coletivos que recuperem essa humanidade levada, que tragam de volta desejos, que nâo favoreça algumas histórias em detrimento de outras. Os sonhos do pequeno anjo de asas partidas lhe dâo força para que ele continue sonhando, para que continuemos sonhando. Para que lutemos por um mundo de justiça, paz social e igualdade. Para que imaginemos um mundo em que todas as formas de exploraçăo, silenciamento, autoritarismo e violência sejam recusadas pelos operantes das relaçôes sociais, políticas e econômicas.

No poema, num único momento essa voz poética deixa de se referir na primeira pessoa do plural e marca a singularidade e a especificidade da experiência do sujeito lírico na primeira pessoa do singular: "Em meio à travessia a humanidade é levada pelas águas e tudo que me fica é uma tênue esperança". Essa voz poética apresenta seu sentimento e já em seguida retorna ao seu compromisso social e coletivo. O que percebemos aqui entâo é um sujeito que nâo limita sua poética à identidade ou à interioridade, mas se volta e se abre para o exterior e para a alteridade. A voz poética marca inquietaçóes e projeçóes que sấo suas, mas igualmente da coletividade, dos grupos que têm projetos em comum consigo. Essa voz se aproxima de vozes que também sonham e lutam por esse mundo de igualdade, respeito e fraternidade. O sujeito poético cria esse espaço ficcional coletivo para vozes que pretendem pensar suas manifestaçôes e açôes sempre a partir dos efeitos que elas podem provocar nas proximidades, no outro.

Michel Collot, ao tratar de poesia objetiva no texto $O$ sujeito lírico fora de si (2013), aborda essas tensōes da produçāo poética.

\footnotetext{
É bem um isso que o poeta deixa falar através da linguagem, mas é para torná-la sua e afirmar-se como Eu em uma relaçăo íntima com essa alteridade irredutível. É esse nó entre identidade e alteridade que funda a responsabilidade da palavra poética, que faz com que o poeta possa responder por ela, e com que nós possamos responderlhe: ele "está carregado da humanidade, dos próprios animais". Na medida em que o poeta traz para a palavra, năo o seu eu, mas esse Eu desconhecido que cada um traz em si, o poema pode nos falar, a nós outros (COLLOT, 2013, p. 231).
}

Para isso, o poeta mobiliza todos os recursos semânticos e poéticos da língua, como destaca Collot. Para o autor, ao promover uma poesia objetiva através dos jogos da linguagem e dos movimentos poéticos, o poeta coloca no primeiro plano um Eu que năo se 
fecha para o exterior, ao contrário, se abre para fora e para o outro. Com isso, o sujeito nâo se isola na sua própria identidade de uma forma fetichista, mas, ao adentrar esses espaços de alteridade, se vê diante do contraditório, do paradoxo, das qualidades e das problemáticas que cercam a açăo humana e o mundo. E desse conjunto de elementos o sujeito é constituído, tal como quando Ponge é citado no trabalho de Marcel Collot: "A variedade das coisas é na realidade o que me constrói" (COLLOT, 2013, p. 235). Esse contato com o exterior é colocado como uma possibilidade de acessar o desconhecido e, consequentemente, algum grau de humanismo. Ao olhar para fora, os próprios movimentos interiores se reconfiguram e se ajustam de acordo com novos sentidos que esse humanismo vai estabelecendo.

Em síntese, o que Marcel Collot (2013) propóe é pensar o sujeito moderno a partir de uma via transitiva, na qual ele se desaproprie e se abra para a alteridade e diversidade do mundo, da linguagem e dos seres. Pensar uma interioridade tornada objetiva que surge do lado de fora, no campo desconhecido e incerto, mas aberto a essa possibilidade de construçáo de um eu integrado a um outro. E um dos resultados que essa poética pode estabelecer é o de demonstrar que, embora nem todos os interesses convirjam para um mesmo ponto, é possível pensar na linguagem como um espaço de reconhecimento de si, do outro e de construçáo de sentidos humanistas e coletivos. Acredito que Da humanidade levada pelas águas, de Graça Graúna, traz algumas dessas marcas. Na última estrofe, o poema fala de uma reaproximaçăo resultante desse processo de olhar para outro e reconhecê-lo na sua especificidade. "Apesar das muralhas e dos arames farpados, o direito à Paz nos aproxima. Viver é perigoso, mas insistimos...". A voz poética fecha com um elemento em comum, algo que aproxima todas essas vozes, que une diferentes experiências em torno de um projeto mais humanitário. Esse é o convite que percorre esse poema de forma subliminar.

Tanto a poética de Conceiçâo Evaristo (2008) quanto a de Graça Graúna (2015) sâo capazes de atingir diferentes pontos da realidade social, mas nâo porque as poetisas impuseram suas intençôes ou eliminaram a autonomia da voz poética cuja fundamentaçăo nasce do próprio processo criativo. W. K. Wimsatt e M. C. Beardsley, em A falácia intencional (1983), falam disso também. Eles argumentam que năo é desejável que se tome a intençấo do autor como referencial de avaliaçăo de uma obra literária. Eles entendem por intençăo "aquilo que se pretendeu" (WIMSATT; BEARDSLEY, 1983, p. 86). É importante destacar a definiçăo desse termo no texto porque ajuda a compreender os objetivos da própria discussâo. "A intençâo é o desígnio ou o plano na mente do autor. A intençấo tem afinidades óbvias com a atitude do autor quanto à sua obra, o modo como sentia, o que o fez escrever" (WIMSATT; BEARDSLEY, 1983, p. 87). Quando o próprio poema tem êxito e atinge o seu objetivo, o poeta também tem a sua intençâo difundida e compartilhada. Mas deve ser o próprio processo criativo responsável por colocar um poema nesse patamar. O poema é linguagem capaz de provocar um movimento na vida humana, funciona como um produto de compreensâo do mundo e é um processo constante de transformaçấo. A linguagem poética é potente e relevante, năo se ignora, nâo se dilui no imediatismo das relaçōes humanas contemporâneas.

Nesse sentido, a intençăo do poema está diretamente vinculada ao falante dramático - ao sujeito lírico -. O sujeito empírico - autor - se aproxima e influi sobre a dinâmica de proposiçôes da poesia na medida em que a sua biografia se apresenta como elemento determinante. “Devemos atribuir os pensamentos e atitudes do poema 
de imediato ao falante dramático e, se de algum modo ao autor, apenas por um ato de inferência biográfica" (WIMSATT; BEARDSLEY, 1983, p. 88). Ao ser criado, o poema năo se limita à intençâo do autor nem às fronteiras estabelecidas pela crítica, mas, ao contrário, ele passa a percorrer diferentes dimensôes de compreensâo e reaçấo diante do público. “O poema năo pertence nem ao crítico, nem ao autor (desliga-se do autor ao nascer e percorre o mundo subtraindo-se ao poder ou ao controle do criador sobre ele). O poema pertence ao público" (WIMSATT; BEARDSLEY, 1983, p. 88). A própria linguagem, ao interagir dentro de cada contexto sócio-histórico e temporal de recepçâo, vai determinar os limites e as proporçôes de impacto do poema. Dessa forma, a produçáo poética responde por si só quais săo seus objetivos à medida que acessa diferentes contextos e realidades. Assim, os efeitos da interaçâo com uma produção poética advêm da própria força da linguagem poética e de sua abertura para o mundo.

Essa abertura está ligada também ao endereçamento lírico. Joëlle de Sermet tem um texto, intitulado $O$ endereçamento lírico (2019), no qual discute justamente suas possibilidades e seus referenciais. Ele analisa entăo a posiçăo da primeira e da segunda pessoas no poema. $\mathrm{O}$ "tu" tem uma posiçâo auxiliar em relaçăo ao "eu". O "tu" é o produto do discurso do enunciador "eu". Esse tu se apresenta como uma imagem. Ele se reflete como objeto inacessível da procura de um ouvinte. Além dessa categoria em que um "eu" se dirige a um "tu", o autor destaca também aquela categoria dos poemas líricos em que o "eu" parece năo se dirigir a ninguém especificamente. Já em suas conclusôes, o pensador defende que o discurso lírico se afasta da contradiçáo entre singularidade e reprodutibilidade (ou universalidade). O poema organiza um diálogo - uma abertura - ao se lançar sobre o sujeito da enunciaçăo e o sujeito da leitura concomitantemente. Consequentemente, ele destaca o papel do leitor. "O leitor sempre é, em graus de implicaçâo variados, derradeiro destinatário, mas também co-destinatário e sujeito do enunciado ao mesmo tempo que sujeito da enunciaçăo" (SERMET, 2019, p. 277). O discurso lírico póe em questăo o estatuto do sujeito - a situaçăo de interlocuçâo como essa interaçăo/diálogo entre um "eu" e um "tu". Ele conclui ressaltando que numa enunciaçáo lírica aquele que fala e aquele a quem se fala nâo constituem entidades isoladas, fixadas em parâmetros inalteráveis. Ao contrário, sâo partes que tencionam na medida em que refletem a própria organicidade dos movimentos psicológicos, sociais, coletivos e históricos.

A compreensāo do endereçamento lírico, penso eu, nos ajuda a estabelecer relaçóes entre a produçăo poética e a nossa experiência no mundo. Saímos entâo da linguagem poética, tocados por ela, e buscamos na realidade formas comuns de reconfigurar a sociedade e tornar nossas relaçōes mais humanas, solidárias e afetivas. Theodor Adorno, no capítulo Palestra sobre lírica e sociedade, do livro Notas de Literatura I (2003), sistematiza de forma muito mais profunda essa relaçăo entre produçăo literária e experiência humana, entre arte e práxis, entre subjetividade e relaçôes coletivas. 0 pensador discute a relaçăo entre o universal e a experiência individual na lírica. Ele destaca que essa universalidade é essencialmente social. Nesse sentido, pensar uma obra de arte é pensar na sua possibilidade de diálogo e de reflexăo social. Entretanto, o pensamento que é resultado desse processo reflexivo năo deve ser uma imposiçấo do interesse da obra nem do autor, mas é algo que emerge da própria complexidade das relaçōes humanas e das contradiçóes que o movimento histórico apresenta. Essa complexidade e essas contradiçóes podem formar o tecido de uma produçăo artística 
atenta ao movimento da humanidade. "O procedimento tem de ser, conforme a linguagem da filosofia, imanente. Conceitos sociais náo devem ser trazidos de fora às composiçôes líricas, mas sim devem surgir da rigorosa intuiçâo delas mesmas" (ADORNO, 2003, p. 67).

Adorno refuta a ideia de que a lírica seja algo oposto à sociedade ou algo totalmente individual. E essas marcas históricas, coletivas, podemos notá-las, por exemplo, na poesia de Conceiçâo Evaristo, de Graça Graúna ou ainda em produçōes poéticas mais recentes como os saraus e slams, se pensarmos em outras produçōes poéticas periféricas. O pensador retoma a proposiçâo de Hegel que apontou que o individual é mediado pelo universal e o universal pelo individual. Nesse sentido, a lírica individual se constitui mediante os papéis coletivos que influem sobre a própria organizaçāo da linguagem, elemento fundamentalmente poético. Toda essa produçâo lírica Conceiçấo Evaristo, Graça Graúna, saraus e slams - apreende as subjetividades que se manifestam através da linguagem e o movimento histórico coletivo também captado pelos recursos estéticos da poesia. Nessas produçôes, a ficcionalizaçáo da voz poética cria um espaço de autorreconhecimento e de alteridade - de reconhecimento do outro - cujos resultados se apresentam numa nova ordem de engajamento e emancipaçăo coletiva. Há um reconhecimento de si no outro e do outro em si mesmo. Em Vozes mulheres (2008), por exemplo, há uma aproximaçăo que visa congregar todas aquelas vozes silenciadas e marginalizadas historicamente e, entâo, colocá-las numa posiçâo de inconformaçăo, luta, resistência e cobrança de transformaçăo da própria ordem histórica e política das coisas.

Toda essa produçăo poética pode se caracterizar como monólogo dramático na medida em que o eu poético expōe muitas das manifestaçōes e sensaçōes da natureza humana que sâo próprias dele, mas também săo de tantos outros que configuram aquele recorte espaçotemporal. E a ficcionalizaçáo poética, que năo se confunde com um simples testemunho nem um registro documental do autor, permite justamente que as marcas da subjetividade e da coletividade se manifestem. E aqui retomo Adorno quando afirma que a lírica năo é oposta à sociedade nem totalmente individual, uma vez que a individualidade também se constitui a partir das mediaçōes do coletivo, das estruturas sociais, culturais, históricas e morais já estabelecidas. Por fim, nesse tipo de produçăo artística, o endereçamento lírico traz as marcas de um eu poético que emerge da própria complexa cadeia de diálogos, tensóes e embates humanos, e se volta para um público que nâo está estagnado no tempo histórico. Ao contrário, esse endereçamento lírico é capaz de permear e adentrar em diferentes recortes temporais e espaciais e, assim, atinge um público - a recepçáo/o ouvinte/o leitor - sempre em movimento e em transformaçăo. A poesia pode ser esse convite ao encontro, ao compartilhamento de lutas e de projetos, pode ser um chamado para que nos reunamos em torno de projetos mais humanitários. 


\section{REFERÊNCIAS}

ADORNO, Theodor W. Palestra sobre lírica e sociedade. In: Notas de literatura 1. Traduçâoo de Jorge M. B. de Almeida. Sâo Paulo: Duas Cidades; Ed. 34, 2003.

COLLOT, Michel. O sujeito lírico fora de si. Traduçăo de Zênia de Faria e Patrícia Souza Silva Cesaro. Signótica, v. 25, n. 1, p. 221-241, jan./jun. 2013.

COMBE, Dominique. A referência desdobrada: o sujeito lírico entre a ficçâo e a autobiografia. Traduçăo de Iside Mesquita e Vagner Camilo. REVISTA USP, Săo Paulo, n. 84, p. 112-128, dezembro/fevereiro 2009-2010.

CULLER, Jonathan. Retórica, Poética e Poesia. In: Teoria literária: uma introduçăo. Traduçăo de Sandra Vasconcelos. Săo Paulo: Beca Produçôes Culturais Ltda., 1999.

EVARISTO, Conceiçấo. Poemas da recordaçăo e outros movimentos. Belo Horizonte: Nandyala, 2008.

GRAÚNA, Graça. art'palavra. Disponível em <https://ggrauna.blogspot.com/2015/09/ da-humanidade-levada-pelas-aguas.html?m=1>. Acesso em: 2 jun. 2021.

PILATI, Alexandre (org.); et al. Monólogo dramático e outras formas de ficcionalizaçăo da voz poética. - 1. ed. - Campinas, SP: Pontes Editores, 2020.

SERMET, Joëlle de. O endereçamento lírico. Traduçăo de Francine Fernandes Weiss Ricieri e Maria Lúcia Dias Mendes. Lettres Françaises, Araraquara, v. 20, ed. 2, p. 261279, 2019. WIMSATT, W. K.;BEARDSLEY, M.C.A FALÁCIA INTENCIONAL. IN: COSTA LIMA, LUIZ (ORG.). TEORIA DA LITERATURA EM SUAS FONTES. RIO DE JANEIRO: FRANCISCO ALVES, 1983, P. 86-102. 